\title{
6
}

\section{Contestable Markets for Entry and Exit}

\subsection{General Principles}

In his 2011 book, Adapt: Why Success Always Starts with Failure, economist Tim Harford highlights three core tenets central to individuals or societies striving to "learn from failure." The first is the importance of variability. In the market, this occurs when firms are heterogeneous and dispersed throughout the economy and differ with respect to size, age, technology, and so forth. As no one can know a priori which business models will be successful, there is a need for a large number of different experiments (Audretsch and Fritsch 2002; Metcalfe 2010). Second, as numerous experiments will inevitably fail, they should be conducted on a sufficiently small scale so that the system as a whole will survive such failure. This survival emerges in the market because all entrepreneurs select the strategy, technology, behavior, and organizational structure they believe could help them outcompete their rivals (Eliasson 1996; Dosi and Nelson 2010; Vivarelli 2013). Finally, Harford (2011) stresses the importance of selection, i.e., that successful experiments be pursued and copied, while unsuccessful ones are identified and quickly terminated. The profit and loss signals conveyed through prices and driven by market competition combine to form an imperfect but crucial selection mechanism. Prices encourage agents to devote resources to their most highly valued use (Hayek 1945), enabling successful firms to survive and grow, while unsuccessful firms exit (Dosi and Nelson 2010). Progress in an entrepreneurial society is not the aim but the result of this evolutionary process, which can only be expected to work if the institutions underpinning the market indeed ensure variability, survival, and selection. 
In this chapter, we address the related policy areas of market regulation, competition policy, and bankruptcy policy. The principles guiding reforms are threefold: contestability, transparency, and justifiability. Contestability here refers to openness to innovation and challengers, which is crucial to markets but also relevant to the soundness of individual firms, bureaucratic organizations, and a host of other contexts; put simply, the system will progress only if it allows better ideas to drive out inferior ones. Furthermore, contestability is most effective when the rules of the game are well defined and guided by transparency: only under this principle can we ensure that potential challengers know what to expect-and what not to expect-when entering a competitive situation.

To safeguard contestability, policymakers must keep incumbent lobbyists at arm's length and refuse their attempts to coauthor the standards, rules, and regulations of their industry. That said, policymakers also have a responsibility to ensure that the challengers' interests are balanced against those of their financiers, employees, customers, and other stakeholders, ensuring that a competitive edge is justifiable and does not come at the cost of the public interest. When they govern markets, these principles help limit the resources that are wasted on losing and flawed projects (Type 1 error) while also avoiding the imposition of undue constraints on winners and successful projects (Type 2 error).

The EU enjoys far-reaching competencies for market regulation, competition policy, and bankruptcy policy. ${ }^{1}$ In addition to opening up markets by enforcing Treaty provisions on the free movement of goods and services and the freedom of establishment, the Commission may order member states to remove legislative and regulatory restrictions on the movement of goods and services and the right of establishment. That said, member states do retain significant regulatory power (Suse and Hachez 2017, p. 63). ${ }^{2}$ Both cooperation in civil matters and the regulation of the internal market are shared competencies, meaning that the EU and its member states jointly shape national bankruptcy and insolvency laws. Furthermore, member states have some room to maneuver where aspects of EU law are subject to minimum standards

\footnotetext{
${ }^{1}$ While the power to regulate the internal market is a shared competence (Article 4(2)(a) TFEU), competition policy is an exclusive Union competence (Article 3(1)(b) TFEU) - to the extent that the anticompetitive conduct has cross-border effects (Articles 101, 102, and 107 TFEU).

${ }^{2}$ First, there is room for deviating from the Treaty rules for purposes of advancing overriding public policy objectives. Second, the power to regulate the internal market is a shared competence: member states retain the power to regulate particular aspects of their markets to the extent that EU law does not already apply. Third, national competition laws apply whenever anti-competitive conduct lacks cross-border effects.
} 
established by a directive (Suse and Hachez 2017, p. 66). ${ }^{3}$ For these reasons, we address all proposals in this chapter to the EU and its member states.

\subsection{Proposals}

\subsubsection{Regulations of Goods and Service Markets}

While environmental, health, safety, and quality regulations are often well motivated and well intended, they can be abused by incumbents to limit entry and competition. It is therefore vital that such regulation is clear, transparent, and neutrally formulated to ensure that new, alternative ways of doing old and new things are permitted. Excessive reliance on rules and procedures discourages potential entrepreneurs and hampers the process of creative destruction, but uncertainty and the absence of clear regulation can be equally damaging.

As a principle, contestability entails preventing market-leading incumbents from building and exploiting a dominant market position by unduly restricting market entry. To this end, low entry barriers are crucial, as is the opening of industries and markets that have thus far barred outside challengers. Within a system characterized by goal-oriented rules, regulations, and public financing, there should be ample room for commercial and cooperative initiatives that challenge the status quo. As a first precondition for contestability, it should be easy and cheap to formally start a venture. ${ }^{4}$

Proposal 32: Excessive barriers to new business formation and new entry should be lifted where possible.

This proposal may have different implications in different countries: in Italy, for example, "excessive" is the operative word, as Italian firm founders report a wide variety of bureaucratic and administrative barriers to starting up a venture. Italy ranks 51 st in the World Bank's ease of doing business ranking, scoring particularly poorly in terms of ease of paying taxes, obtaining credit,

\footnotetext{
${ }^{3}$ The EU has no explicit legal basis in the Treaties to adopt bankruptcy and insolvency legislation. However, the provisions of Article 81 of the TFEU, on judicial cooperation in civil matters, and the harmonization clauses in Articles 114 and 115, may serve as legal bases for enacting EU law in this area. ${ }^{4}$ Figure A.3 in the Appendix shows how the EU countries compare with respect to the ease of starting a business relative to the USA and New Zealand, which are the leading countries. Countries such as Germany, Austria, and Malta show considerable room for improvement, while the western EU countries have high overall scores on this measure. Apart from Poland and the Czech Republic, this is also the case for the Eastern European countries.
} 
and enforcing contracts (World Bank 2018). There is also room for improvement in Germany, which ranks on par with Georgia in the ease of starting a business, with founders perceiving bureaucracy and regulation as barriers to business formation (Sanders et al. 2018b). Austria, Poland, and the Czech and Slovak Republics find themselves in similarly dire positions (World Bank 2018).

An entry barrier warranting special attention is occupational licensing, which was originally intended to ensure the quality of services that consumers are unable to determine themselves. In theory, the license indicates that the provider is capable and abides by the rules, ensuring a minimum quality level of the service. In practice, however, occupational licensing often results in unjustified profit opportunities for license holders and abuse of market power, rather than consumer protection. Today, Europe's regulated professions involve more than 50 million people or $22 \%$ of total employment (European Commission 2015a; Koumenta and Pagliero 2017). Evidence from the USA and the EU shows that such regulation has a significant impact on prices and labor mobility, while little to no evidence supports the claim that quality is higher (Kleiner 2000; Kleiner and Krueger 2010, 2013; Johnson and Kleiner 2017; Koumenta and Pagliero 2017; Bowblis and Smith 2018; Barrios 2018). It seems that such protection no longer serves its original purpose: according to the European Commission (2015a, p. 7), "many of these regulations are now disproportionate and create unnecessary regulatory obstacles to the mobility of professionals, lowering productivity" (cf. Erixon and Weigel 2016).

The Services Directive and the Professional Qualifications Directive ${ }^{5}$ give the Commission extensive competencies concerning occupational licensing, and a rigorous process of evaluation of regulated professions has been put in place as part of the European Semester. Member states have implemented reforms and opened up such professions, ushering in more jobs and lower prices while maintaining service quality (Koumenta and Humphris 2015; Pagliero 2015; Athanassiou et al. 2015). Thus far, the Commission has devoted its liberalization attempts to occupations such as civil engineers, architects, accountants, lawyers, real estate agents, tourist guides, and patent agents (European Commission 2015a), but a list of some 6468 regulated occupations is under systematic review (European Commission 2019a).

\footnotetext{
${ }^{5}$ Directive 2005/36/EC, recently amended by Directive 2013/55/EC.
} 
Occupational licenses imply that contestability is curtailed. ${ }^{6}$ They keep challengers out and lock incumbents in, thereby reducing allocative efficiency and innovation. These consequences directly affect the flow of labor into and out of new ventures. Recognizing that occupational licensing is already on the EU policy agenda, we propose, in line with all three principles above:

Proposal 33: Create transparent and open systems of occupational certification, such that people can easily move across occupations and in and out of new ventures.

Product market reform is the second ingredient in the European integration effort; European policymakers consider similar product market regulations in all EU countries to be necessary to transform the EU into a single market. Despite several rounds of deregulation, however, member states still exhibit substantial differences in the extent of their product market regulations. Differences in service sector regulations are still larger. As Fig. 6.1 shows, the two measures are strongly correlated; countries with highly regulated product markets tend to have strictly regulated service markets as well. Arguably, reducing this complexity and opacity is easier said than done because policymakers typically allow lobbyists and incumbents to influence the process. Granted, one should not ignore the genuine interests of incumbents offhand; they often provide valuable technical know-how and facilitate the adoption of new standards and regulation. Nonetheless, a more detailed and complex system should be avoided because it works in incumbents' favor vis-à-vis potential challengers, running counter to the principles of contestability and justifiability.

Proposal 34: Continue to harmonize and liberalize product and service markets in the Union by setting functional and transparent minimum requirements and limiting the influence of lobbyists.

We should note that there is little correspondence between the indices of product and service market regulations and the World Bank's (2018) ease of starting a business index. For example, Austria and Germany score poorly in terms of the ease of starting a business despite their lenient product and service market regulations. The discrepancy is probably observed because a great

\footnotetext{
${ }^{6}$ For example, Koumenta and Pagliero (2017) find that foreign-born practitioners are underrepresented by about one-third in licensed occupations, but no similar discrepancy in unregulated or certified occupations. Moreover, certified workers invest more in training than licensed workers, but the latter earn a wage premium of about $4 \%$ on average.
} 


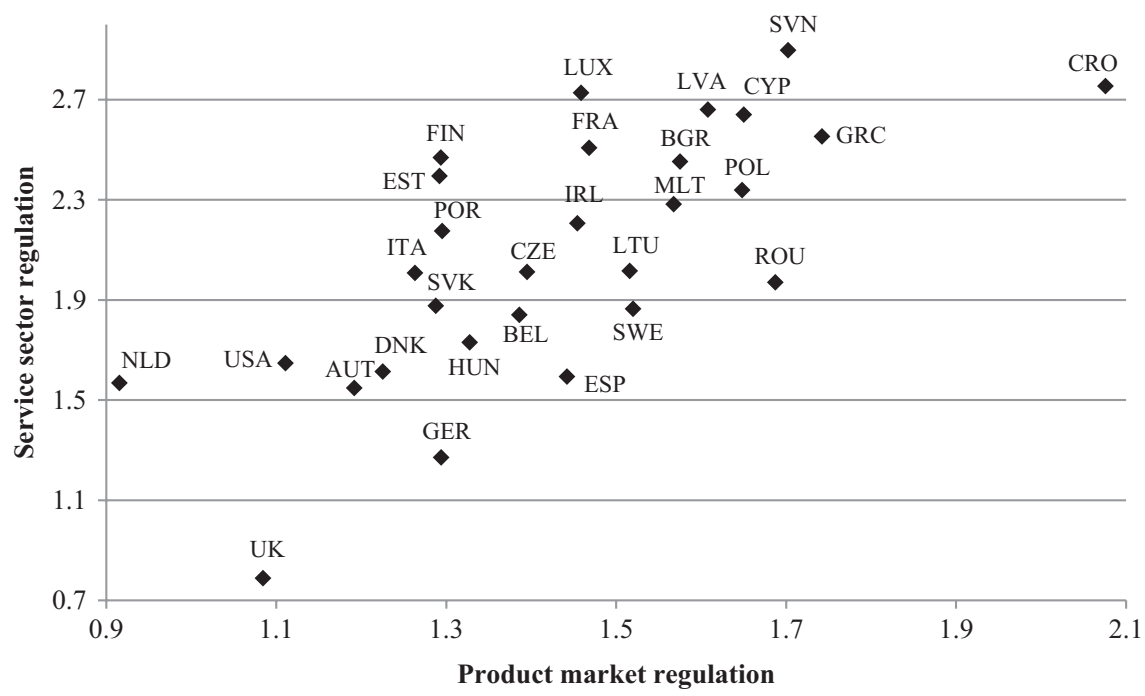

Fig. 6.1 Strictness of product and service market regulations in EU countries and the USA, 2013. Note: The scale of the index is $0-6$, where a larger number means a more stringent regulation. 2013 is the latest available year. The product market regulation index is OECD's aggregate indicator; the service sector index is the arithmetic average of the OECD indices for professional services, retail trade, and the network sectors (transportation, energy, telecom, and mail). The indices are based on responses of national governments to the OECD Regulatory Indicator Questionnaires. Source: OECD, Product Market Regulation Database

deal more is involved in setting up a firm than just product market regulations; excessive taxes, red tape, and poor conditions for financing matter a great deal as well. Removing such obstacles is part and parcel of the EU policy agenda already, and we encourage these efforts, with the caveat that well-justified barriers to entry can be useful to keep unproductive and destructive ventures out (Stenholm et al. 2013; Darnihamedani et al. 2018). While it should be easy for challengers to enter (and exit) markets, these challengers should be serious and professional. Regulation that sets reasonable and functional restrictions on new ventures helps prescreen challengers on quality.

This seems particularly relevant in the regulation of publicly provided services. With "publicly provided services," we here refer to collectively financed services provided by a government to people within its jurisdiction, whether directly (through the public sector) or by financing service provision. These services are relevant for the future of Europe's entrepreneurial ecosystem for multiple reasons. First, demand in these sectors is growing: the share of health and education in total GDP is rising in all advanced countries due to demographic and technological trends. Arguably, another driver is Baumol's cost disease: the rise of salaries in jobs that have experienced no or a low increase 
in labor productivity in response to rising salaries in other jobs that have experienced higher labor productivity growth. ${ }^{7}$ In the long run, the rising demand for public services is unlikely to be satisfied, barring significant efficiency improvements and entrepreneurship-driven innovation. If onerous regulation limits access for challengers in these domains, the long-run consequences can be detrimental for the economy as a whole. However, reforms to open up these areas for private initiatives should not take the form of naïve wholesale privatization and laissez-faire. Evidence from the USA suggests that privatized healthcare and education are not necessarily cheaper or better; again, much depends on the institutional framework that makes these special markets work (Reinhardt et al. 2004; Squires 2012).

That said, although there are ways to introduce contestability in public sector organizations, it is easier to do so in a market context. The challenge for policymakers is to ensure quality and access to health care and other social services without resorting to full bureaucratic regulation and public production. Doing so likely involves the clever combining of partially open markets with strict legal and institutional frameworks while drawing a clear line between the market domain and the bureaucratic domain. A case in point could be the Dutch system of universal private health insurance: introduced in 2006, it requires private suppliers to offer a standardized policy at a (competitive) price while obliging all citizens to buy such a policy (Schäfer et al. 2010). Competition on coverage is prohibited, and private insurance providers must accept all applicants, leaving price and quality as the sole dimensions on which to compete.

The deregulation of some health and public services promises to open entirely new arenas for private innovation and entrepreneurial venturing, even if direct public financing is likely to remain the default option in most EU countries. Of course, confounding factors, such as strong asymmetries in information and market power or economies of scale and scope, can effectively preclude market systems as a viable option. When this happens, the public sector can still organize contestability in bureaucratic organizations by giving users a "right to challenge" public sector provision ${ }^{8}$ and by holding

\footnotetext{
${ }^{7}$ Liu and Chollet (2006) find income and price elasticities of demand of about $0.1-0.2$ for healthcare services in the short run. The evidence suggests that in the short run people have no choice but to demand the services regardless of income and price, whereas, in the long run, the demand for these services rises faster than GDP. The long-run income elasticity for health care and education, however, is probably closer to 1.6 (Fogel 1999). In relation to Baumol's (2012) cost disease, this fact implies that a rapidly rising share of income and employment in the total economy will be absorbed in these sectors.

${ }^{8}$ In the UK, for example, the right to challenge is instituted as a right for local communities to challenge public sector provision of rescue and firefighting services. There are also examples of community-based challengers in care and social service provision. See, e.g., My Community (2019).
} 
competitions on relevant dimensions among smaller organizational units. In line with the principle of contestability, we therefore propose the following:

Proposal 35: Undertake the responsible deregulation of publicly provided services to introduce contestability into these growing areas of the economy.

One challenge to the implementation of the proposals is the fact that consumers can rarely assess the quality of the service provided or discipline producers directly. If countries are to tap the potential and handle the challenge of this combination of semi-public financing and semi-private production, they must create novel institutional arrangements and dare to experiment. When the state acts as an intermediary for an absent third party (the taxpayers) and removes market discipline on producers, no level of competition or freedom of choice will eliminate the scope for manipulation and rent seeking. ${ }^{9}$ Moreover, producers typically have limited options to offer and charge for extra quality beyond what a bureaucratically organized and tax-financed system prescribes. When equal access is considered more important than maximum efficiency, such as in basic health care, such constraints can be justifiable; in other instances, policymakers could achieve welfare improvements by allowing for more private for-profit and nonprofit initiatives in the social domain.

Proposal 36: Allow experiments with private actors providing public services in carefully designed markets and learn from these experiments.

The regulatory framework discussed here governs activities characterized by a mixture of private production and public financing. Unless they experiment with this framework, countries cannot reap the full benefits of innovation and entrepreneurial initiatives. Allowing private initiatives in these areas would also create investment opportunities for Europe's institutionalized savings through VC firms, thereby spurring innovation in the social domain.

Hovering over the issue of market contestability is the current trend in the EU towards digitalization-a development that, like most developments, presents both opportunities and challenges. The digital revolution is beginning to change the way we organize society across the board, touching on the very institutions that allocate capital, labor, and knowledge in society (deGryse 2016; Ferrari 2016; Mackenzie 2015; Lin et al. 2009). Currently, the Nordic countries, the Netherlands, and the UK rank high in terms of networked

\footnotetext{
${ }^{9}$ Welfare services are supplied and consumed in the so-called quasi-markets that are characterized by a series of problems that must be addressed, see Le Grand and Bartlett (1993).
} 
readiness (WEF 2016). Laggard countries such as Germany can improve their ranking, providing fertile ground for new firm formation and promoting a more dynamic and innovative entrepreneurial ecosystem without jeopardizing their existing routine-based, incremental innovation paradigms (Sanders et al. 2018b). If policymakers proactively embraced the digitalization trend, they would allow entrepreneurs to act on the new opportunities that technology offers while protecting European citizens from the risks.

Digitalization also brings with it strong positive network externalities, which offer a compelling argument for collective action: A no-regret policy would be to provide an excellent, publicly financed, Information and Communications Technology (ICT) infrastructure in Europe that allows entrepreneurs to scale up their innovative ideas to the EU level and beyond in a rapid fashion. Such an effort would integrate more European citizens in the common market for digital services and facilitate information exchange, essentially enabling them to act as venturesome consumers (Bhidé 2008). In essence, building an open platform for European entrepreneurs would promote contestability by increasing transparency.

Proposal 37: Invest in excellent, open access digital infrastructure for European citizens and businesses.

In addition to providing European entrepreneurs and consumers with a springboard to the global marketplace, a high-quality ICT infrastructure is also essential in the urgently needed transition to a circular economy; that is, an economic system aimed at minimizing waste and making the most out of resources (Ellen MacArthur Foundation 2013; European Commission 2012). Currently, our economic model is geared towards a linear model of production from virgin resources to waste (Haas et al. 2015), where prices are believed to convey the most relevant information regarding production and opportunity costs throughout the value chain. However, price alone no longer conveys the most relevant information, and information flows are increasingly becoming both multidimensional (concerning quality, origin, ecological impact, etc.) and multidirectional (running, for example, from users to intermediate producers and back). Circular business models are better placed to address these complexities but also require much more intense cooperation and communication throughout the value chain (Subramanian and Gunasekaran 2015). The same holds for the more intense use of peer-to-peer lending and equity crowdfunding, proposed in Chap. 4: Lin et al. (2013) show that even the social media contacts of borrowers convey valuable information to lenders. A reliable and secure ICT infrastructure managing more complicated 
information flows could be a prerequisite for the transition to a more sustainable economy. This justifies public investment and interventions to create a transparent and open digital infrastructure.

Proposal 38: Develop open but responsible standards and open regulation for the many digital platforms that emerge to facilitate peer-to-peer and businessto-business trade, services and finance.

That said, carefully considering the position of workers and customers on these platforms is essential. Frenken et al. (2017), for example, voice concern about the quality of work and the possibility that digital platforms may undermine social security. Additionally, privacy issues, digital rights, and consumer protection remain important areas of EU policy. Technological developments necessitate the careful modernization of labor market protection and social security systems (in line with proposals in Chap. 5) and adequate investment in human capital (in line with proposals in Chap. 7) to ensure that digitalization contributes to inclusive growth.

The EU could be instrumental in establishing standards that would boost European entrepreneurship on digital platforms. ${ }^{10}$ Given its leading position in terms of platform-based financial innovation, the UK was in an excellent position to set such standards before Brexit (Sanders et al. 2018c). Now, the torch will have to pass to the Netherlands and the Nordic countries, as they also have a high degree of network readiness (WEF 2016).

\subsubsection{Bankruptcy Law and Insolvency Regulation}

The entrepreneurial ecosystem is experimental at its core, which makes frequent failure inevitable and, to some extent, desirable. Failed projects should not be considered a waste of resources, and bankruptcies are neither unproductive nor destructive; instead, firm failure provides valuable information to economic agents about whether a business model is viable. Failed ventures must end so that their resources can be turned to more productive uses, but "fear of failure" should not prevent new entrants from challenging the status quo. Learning by failure is of paramount importance for both the entrepreneur and society. Moreover, a restructured venture with new management or

\footnotetext{
${ }^{10}$ The proposals in this subsection are well aligned with the Commission's Digital Single Market initiative, it's Circular Economy Package (European Commission 2017c), and the Digital Agenda (European Commission 2014). The European Commission has substantial legal competencies and supportive measures available to act in this domain.
} 
a different firm can often recycle and improve upon the knowledge and ideas from failed projects, making past failure the foundation for future success. Of course, failure also implies that people suffer, psychologically and financially, and such damage should be minimized. Thus, it is reasonable to institute relatively generous bankruptcy laws and insolvency regulations, with provision for discharge clauses, the postponement of debt service and repayment, and the possibility of restructuring.

Efficient handling of ailing firms calls for bankruptcy and insolvency regulation that minimizes the time and costs to society in phasing out unprofitable and inefficient firms while limiting the damages for creditors, customers, suppliers, employees, and the government. Importantly, a distinction must be made between insolvent firms, which should be closed down, and illiquid ones, which should be allowed to remain operative. A firm is insolvent when the value of its assets is less than its debt and its equity is negative. However, a firm could be unable to honor its obligations simply because it is experiencing temporary financial difficulties. If so, the best solution for both the firm and its creditors is debt restructuring and possibly reduction (a "haircut") through negotiations with the firm's creditors to avoid a "fire sale" of valuable firm assets.

As Fig. 6.2 shows, Finland and Germany have the best regulatory framework for insolvency among the EU countries-Finland even scores better

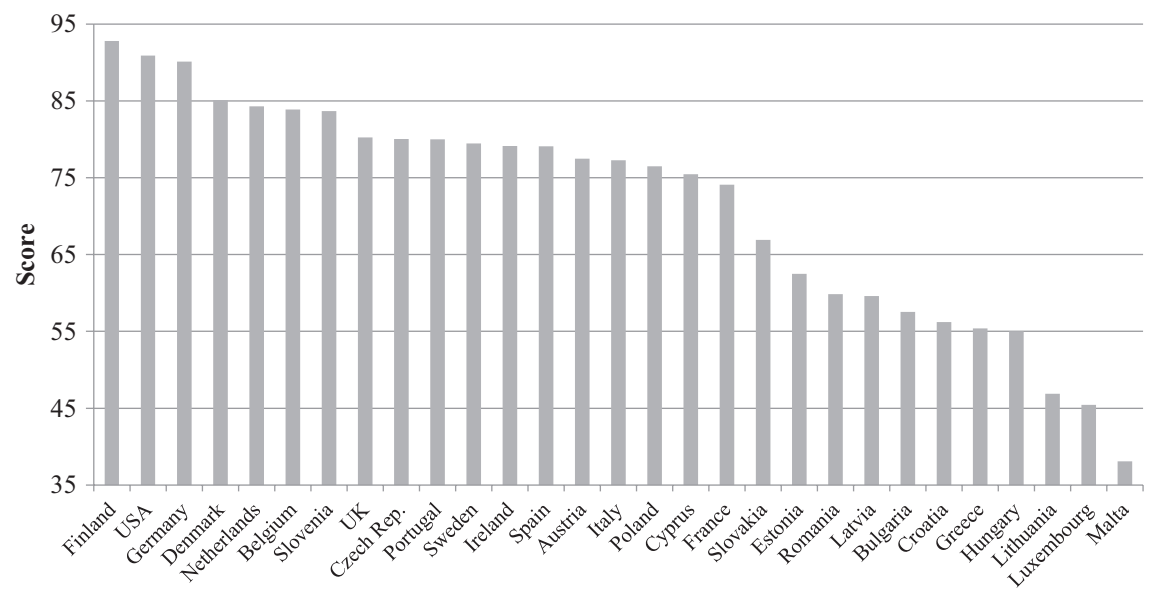

Fig. 6.2 Ease of resolving insolvency in EU member countries and the USA, 2018. Note: The ranking of economies on the ease of resolving insolvency is determined based on their distance to frontier scores for resolving insolvency. These scores are the simple average of the distance to frontier scores for the recovery rate and the strength of insolvency framework index. Finland is also the most highly ranked country in the world. Source: World Bank, Doing Business 2018 
than the USA (World Bank 2018) —and the rest of Western Europe also scores high (with the notable exception of Luxembourg). Meanwhile, the Eastern European and Mediterranean countries rank low, with Portugal, Slovenia, and Cyprus being interesting exceptions (World Bank 2018). Overall, the picture suggests substantial room for improvement.

Reform efforts should strive for insolvency regulation that protects inherently healthy and promising ventures while smoothly putting bad ventures to rest once the verdict is clear. If they are too hastily shut down, with their remaining assets shifted out to creditors, the result could be excessive value destruction. Not all insolvent operations should be considered a failure: it is often sufficient that the current owners lose their equity, that the debt is restructured, and that the consortium of debtors finds a new controlling owner after restructuring (Becker and Josephson 2016). Reforms taking these concerns into account would be in line with the principle of justifiability, as they balance the interests of the entrepreneur and other stakeholders in the venture.

Proposal 39: Insolvency regulation should protect ventures that are inherently healthy and promising and allow for a quick and ex ante transparent liquidation of those that are not.

The European Commission adopted a recast of the Insolvency Regulation Directive in 2015. Moreover, under its Capital Markets Union program, the Commission has proposed a business restructuring directive. If implemented, it would provide the tools to rescue viable businesses and give honest, albeit, bankrupt entrepreneurs a second chance (European Commission 2016; Stamegna 2018). Given the persistent variation in insolvency regulation across Europe, the Commission's reform agenda in this area is laudable.

Unfortunately, "fear of failure" cannot be eliminated by efficient and effective insolvency regulation alone. Such attitudes depend, in no small measure, on a cultural dimension that differs markedly across the EU. To the extent that reforms of formal institutions affect citizens' attitudes about entrepreneurial venturing, such effects will only materialize in the long run. Nevertheless, if policymakers signal to society that business failure is acceptable, cultural attitudes can gradually become more supportive (Sanders et al. 2018b).

Furthermore, while laggard countries must improve their insolvency regulation to become more innovative and entrepreneurial, this cannot be done in isolation. Policymakers must combine reforms in this direction with a strengthening of the rule of law, government effectiveness, and the security of 
property rights (Chap. 2); otherwise, reforms will prove ineffective or even facilitate abuse and fraudulence. An insolvency regulation such as Finland'swhich strikes a sound balance between protecting and restructuring inherently healthy firms, discouraging rent seeking, and encouraging entrepreneurial risk-taking-may fail miserably in Romania or Greece. As such, forgiving insolvency regulation is only feasible when countries also rank highly on the most fundamental rules of the game. Portugal and Slovenia provide what may be a second-best solution in this respect: given their apparent success, it is probably a wise, low-risk strategy for countries with similar institutional configurations to undertake reforms akin to theirs, so as not to base their reform strategy on non-existing high-quality legal institutions.

Finally, we believe it would be a waste of resources not to draw lessons from failed ventures: much of this knowledge is tacit and hard to record and transmit, but that which can be saved should not go to waste. However, the transferrable knowledge generated by failed ventures is lost if entrepreneurs do not record or share it. Because private incentives to do so are absent, it makes sense to publicly fund the collection, curation, and diffusion of such knowledge. The creation of entrepreneurial knowledge observatories would help to diffuse such knowledge to potential investors, would-be entrepreneurs and academic researchers alike, especially when combined with open access data on, for example, crowdfunding campaigns. Therefore, and in line with our principle of transparency, we propose the following:

Proposal 40: Set up publicly funded "entrepreneurial knowledge observatories" where knowledge accumulated in the entrepreneurial process is collected, curated, and freely diffused.

Because the generated knowledge is typically highly context dependent and firm specific, it makes sense to create the observatories in the ecosystems or collaborative innovation blocs where entrepreneurial entry and exit rates are high. For example, it would be valuable to locate an observatory in London, since the UK's entrepreneurial venturing is highly concentrated there, to further strengthen the ecosystem. In countries such as Italy or Germany, where start-up activity is much less geographically concentrated, the strategic formation of a few observatories could help create clusters that can grow into national hotbeds for new firm formation. 


\subsection{Summary}

Contestability ensures progress in an entrepreneurial society: Only when new entrants can challenge the status quo and selection takes place on merit will the market's evolutionary process yield the kind of creative destruction that drives innovation and growth (Schumpeter 1934 [1911]). To achieve contestability, entry and exit barriers must be low, transparent, and functional. Moreover, vital infrastructure must be accessible to challengers and incumbents alike. Finally, the knowledge generated in the entrepreneurial process must, to the extent that it is possible, be shared and used, even when-or perhaps especially when - a venture fails. Table 6.1 provides a summary of our proposals regarding contestable markets for entry and exit, specifying the level in the governance hierarchy that should make the necessary decisions.

The EU has extensive competencies in regard to the regulation of product markets and ensuring the mobility of capital, labor, goods, and services in the single market. These instruments should be used to ensure that challengers can compete on a level playing field with incumbents. EU competencies are also strong in regard to competition regulation and supervision as well as state aid and public procurement, but here, in view of the political backlash of the financial crisis, it is probably wise to allow the member states themselves to experiment with new governance models and allow for more contestability in public service provision. Once experimentation has provided an evidence base that can be used to formulate specific reforms, the EU should become involved opening up public sector services for more competition.

In regard to the resolution of insolvency and the management of highly region-specific knowledge, the Union does not seem to be the most appropriate level for policymaking; regional and local policymakers are probably better placed to combine the proposed knowledge observatories with their current policies on regional and local business development. 
Table 6.1 Summary of proposals regarding contestable markets for entry and exit, specifying the level in the governance hierarchy where the necessary decisions should be made

\begin{tabular}{|c|c|c|c|c|}
\hline No. & Principle(s) & $\begin{array}{l}\text { Policy } \\
\text { area }\end{array}$ & Proposal & $\begin{array}{l}\text { Policy } \\
\text { level }^{a}\end{array}$ \\
\hline 32 & Contestability & $\begin{array}{l}\text { Entry } \\
\text { barriers }\end{array}$ & $\begin{array}{l}\text { Excessive barriers to new business } \\
\text { formation and new entry should be } \\
\text { lifted where possible. }\end{array}$ & $\begin{array}{l}\text { EU, MS, } \\
\text { REG, LOC }\end{array}$ \\
\hline 33 & $\begin{array}{l}\text { Contestability, } \\
\text { transparency, and } \\
\text { justifiability }\end{array}$ & $\begin{array}{l}\text { Entry } \\
\text { barriers }\end{array}$ & $\begin{array}{l}\text { Create transparent and open } \\
\text { systems of occupational } \\
\text { certification, such that people can } \\
\text { easily move across occupations and } \\
\text { in and out of new ventures. }\end{array}$ & EU, MS \\
\hline 34 & $\begin{array}{l}\text { Contestability and } \\
\text { justifiability }\end{array}$ & $\begin{array}{l}\text { Entry } \\
\text { barriers }\end{array}$ & $\begin{array}{l}\text { Continue to harmonize and } \\
\text { liberalize product and service } \\
\text { markets in the Union by setting } \\
\text { functional and transparent } \\
\text { minimum requirements and limiting } \\
\text { the influence of lobbyists. }\end{array}$ & EU \\
\hline 35 & Contestability & $\begin{array}{l}\text { Entry } \\
\text { barriers }\end{array}$ & $\begin{array}{l}\text { Undertake the responsible } \\
\text { deregulation of publicly provided } \\
\text { services to introduce contestability } \\
\text { into these growing areas of the } \\
\text { economy. }\end{array}$ & EU, MS \\
\hline 36 & $\begin{array}{l}\text { Contestability and } \\
\text { justifiability }\end{array}$ & $\begin{array}{l}\text { Entry } \\
\text { barriers }\end{array}$ & $\begin{array}{l}\text { Allow experiments with private } \\
\text { actors providing public services in } \\
\text { carefully designed markets and } \\
\text { learn from these experiments. }\end{array}$ & MS \\
\hline 37 & $\begin{array}{l}\text { Contestability and } \\
\text { transparency }\end{array}$ & ICT & $\begin{array}{l}\text { Invest in excellent, open access } \\
\text { digital infrastructure for European } \\
\text { citizens and businesses. }\end{array}$ & $\begin{array}{l}\text { EU, MS, } \\
\text { REG, LOC }\end{array}$ \\
\hline 38 & Transparency & ICT & $\begin{array}{l}\text { Develop open but responsible } \\
\text { standards and open regulation for } \\
\text { the many digital platforms that } \\
\text { emerge to facilitate peer-to-peer } \\
\text { and business-to-business trade, } \\
\text { services, and finance. }\end{array}$ & EU \\
\hline 39 & Justifiability & Insolvency & $\begin{array}{l}\text { Insolvency regulation should } \\
\text { protect ventures that are inherently } \\
\text { healthy and promising and allow } \\
\text { for a quick and ex ante transparent } \\
\text { liquidation of those that are not. }\end{array}$ & EU, MS \\
\hline 40 & Transparency & Insolvency & $\begin{array}{l}\text { Set up publicly funded } \\
\text { "entrepreneurial knowledge } \\
\text { observatories" where knowledge } \\
\text { accumulated in the entrepreneurial } \\
\text { process is collected, curated, and } \\
\text { freely diffused. }\end{array}$ & REG, LOC \\
\hline
\end{tabular}

aEU federal level, MS member state level, REG regional government level, LOC local/ municipal level 
Open Access This chapter is licensed under the terms of the Creative Commons Attribution 4.0 International License (http://creativecommons.org/licenses/by/4.0/), which permits use, sharing, adaptation, distribution and reproduction in any medium or format, as long as you give appropriate credit to the original author(s) and the source, provide a link to the Creative Commons licence and indicate if changes were made.

The images or other third party material in this chapter are included in the chapter's Creative Commons licence, unless indicated otherwise in a credit line to the material. If material is not included in the chapter's Creative Commons licence and your intended use is not permitted by statutory regulation or exceeds the permitted use, you will need to obtain permission directly from the copyright holder.

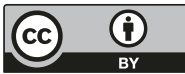

